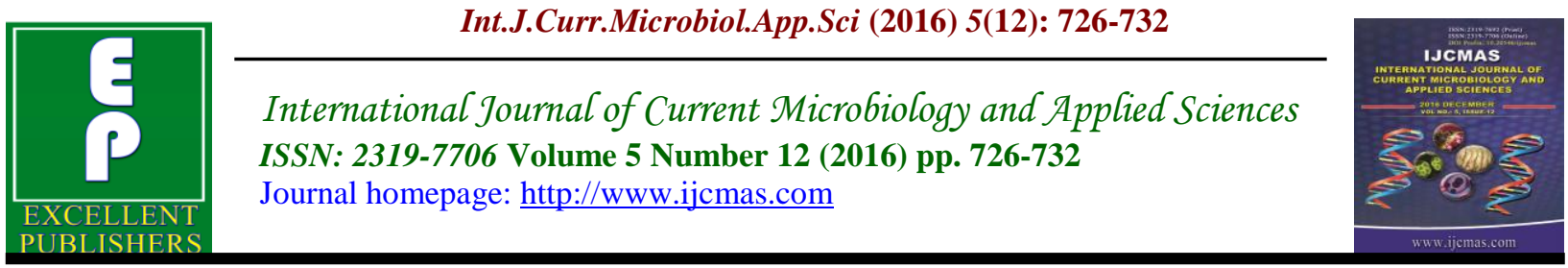

Original Research Article

http://dx.doi.org/10.20546/ijcmas.2016.512.083

\title{
Molecular Detection of Citrus Yellow Mosaic Virus (CYMV) and Citrus Greening Bacterium (CGB) in Sathgudi Sweet Orange by Duplex Polymerase Chain Reaction (dPCR)
}

\author{
V. Gopi ${ }^{1}$, T. Gouri Sankar ${ }^{1}$, K. Gopal ${ }^{2 *}$ and L. Mukunda Lakshmi ${ }^{1}$ \\ ${ }^{1}$ Molecular Diagnosis Laboratory, Citrus Research Station, Dr. Y.S.R. Horticultural University, \\ Tirupati - 517 502, Andhra Pradesh, India \\ ${ }^{2}$ College of Horticulture, Dr. Y.S.R. Horticultural University, Anantharajupeta - 516105 , \\ Andhra Pradesh, India \\ *Corresponding author
}

Keywords

Citrus Yellow

Mosaic Virus

(CYMV), Citrus

Greening Bacterium

(CGB), Duplex

PCR, Simultaneous

Detection.

\begin{tabular}{l}
\hline Article Info \\
\hline Accepted: \\
26 November 2016 \\
Available Online: \\
10 December 2016
\end{tabular}

\section{Introduction}

Citrus is one of the important fruit crops grown throughout the world. It is grown in more than 50 countries of the world and is one of the choicest fruits having high consumer's preference both as fresh fruit as well as for its refreshing processed juice. Citrus cultivation is facing plethora of production constraints viz., Non availability of disease free planting materials, bud wood transmissible diseases, scarcity of water for irrigation, cultivation in unsuitable soils, etc. Citrus species is prone to 150 types of diseases \& disorders by fungal, viral, bacterial infections. Some of these diseases are Greening, Tristeza, Ring spot, Mosaic, Ganoderma Root Rot, Powdered Mildew, 
and Anthracnose or whither tip, Sooty mould, Blue mould.

Citrus yellow mosaic virus (CYMV) disease is common disease where ever Citrus is grown as a commercial crop. In India CYMV was first described by Murthi and Reddy (1975). It was later studied in detail by Ahlawat et al., (1985, 1996a and 1996b). Main symptoms in field trees were mosaic pattern with irregular yellow or light green patches alternating with normal green leaf area irregularly distributed all over the leaf without any definitive pattern (Fig. 1A). The losses caused by the mosaic disease were apparent in Sathgudi sweet orange orchards in Andhra Pradesh and Karnataka because several orchards with trees 4 to 10 years old were abandoned since they were no longer productive. The reduction in fruit yield was $77 \%$ in 10 years old trees and fruit from affected trees had $10 \%$ less juice and ascorbic acid (Reddy and Murti, 1985). It was described as a new graft transmissible disorder in sweet orange characterized by yellow mottling of leaves and yellow flecking along the veins.

Citrus Huanglongbing (HLB), earlier known as citrus greening disease (CGD), is one of the most destructive diseases of citrus and responsible for decline in AP and elsewhere in the country (Ahlawat et al., 1995; Bove et al., 1996; Gopal et al., 1999, 2001). Symptoms caused by HLB were characterised by yellowing of veins and adjacent tissues, followed by premature defoliation, dieback of twigs, decay of feeder rootlets and lateral roots, decline in vigour, and ultimately the death of the trees (Fig. 1B). Diseased leaves become hardened and turn outward, while young leaves, which develop after premature defoliation, are small and slender with symptoms resembling those of zinc deficiency. Trees affected with greening become stunted, bear multiple off season flowers, most of which fall off, and produce small misshapen fruit with thick, pale green peel.

The citrus pathogens are inadvertently disseminated through budwood as it is the main source of vegetative material for propagation. Therefore, a reliable and sensitive detection technique is needed, which can detect the bacterial and virus pathogens, preferably simultaneously. Such a technique may help in the prevention and spread of these pathogens. Serological methods for the detection of both pathogens are not preferred as badnaviruses including CYMV are moderately immunogenic (Lockhart and Olszewski, 1993) and production of antibodies involves unusually complex virus purification and immunization steps. The detection of the bacterium by ultrathin electron microscopy is a satisfactory method but due to erratic distribution of the bacterium and nonavailability of electron microscope in most laboratories, this method has limited application. However, several indirect approaches, such as monoclonal antibodies and DNA probes, have been used for diagnosis. Although, the use of monoclonal antibodies for field diagnosis has proven unsatisfactory because of strain specificity (Korsten et al., 1993; Varma et al., 1993) the use of specific DNA probes has proven to be more reliable and as sensitive as the electron microscopy (Jagouiex et al., 1996) but it is time consuming.

Recently, both the pathogens have been detected by a standard PCR, using the DNA extracted from leaf for CYMV (Baranwal et al., 2003) and from midrib and petiole for CLa (Hocquellet et al., 2000; Ahlawat et al., 2003). In view of the increasing interest in plant pathology for the detection of more than one targets, such as mixed infection (Fig. 3) of viruses and bacteria (Bertolini et 
al., 2003), and viroids and viruses (Singh and Nie, 2003) in single reaction, multiplex PCR protocols have been developed. We describe a duplex PCR for the detection of a bacterium and a DNA virus frequently infecting sweet orange trees.

\section{Materials and Methods}

\section{Plant Materials}

Mixed infected samples (CGB and CYMV) were collected from Sathgudi sweet orange trees at Citrus Research Station, Tirupati.

\section{DNA Isolation}

DNA isolation and PCR detection of HLB and CYMV in sweet orange. The addition of sodium sulphite to Tris-EDTA to reduce the degradation of DNA (Gopal et al., 2007) was followed for extraction of DNA. One $\mathrm{ml}$ of extraction buffer $(0.1 \mathrm{M}$ Tris- $\mathrm{HCl}(\mathrm{pH}$ 8.0), $10 \mathrm{mM}$ EDTA, $1 \mathrm{M} \mathrm{KCl,} 0.65 \%$ sodium sulphite) was added to the ground tissue in an Eppendorf tube and incubated at $95^{\circ} \mathrm{C}$ for 10 min with occasional agitation.

The homogenate was placed on ice for $2 \mathrm{~min}$ and centrifuged for $10 \mathrm{~min}$ at $12000 \mathrm{rpm}$. The supernatant was treated with Rnase (100 $\mathrm{mg} / \mathrm{ml}$ ) and the DNA was precipitated with 0.6 vol of ice-cold isopropanol. After centrifugation, sterile distilled water was added to the precipitate and heated briefly to $65^{\circ} \mathrm{C}$ to completely dissolve DNA. DNA was re-precipitated with 2 vol of ethanol and 0.1 vol of sodium acetate $\left(\mathrm{pH} \mathrm{5.2)}\right.$ at $-20^{\circ} \mathrm{C}$ for overnight. After incubation the tubes were centrifuged at $12000 \mathrm{rpm}$ for $15 \mathrm{~min}$. The pellet obtained was washed with $70 \%$ ethanol $(100 \mu \mathrm{l})$ and centrifuged at 12000 rpm for 5 min. The pellet obtained was air dried, dissolved in TE buffer and stored at $20^{\circ} \mathrm{C}$ for further use.

\section{PCR amplification}

PCR was performed in $50 \mu 1$ of reaction mixtures, using $1 \mu \mathrm{M}$ of each primer (Table 1), $200 \mathrm{mM}$ each of dNTPs, $0.05 \mathrm{U} / \mu \mathrm{l}$ of Taq DNA polymerase, $1 \mathrm{X}$ PCR reaction buffer, $2.0 \mathrm{mM}$ of $\mathrm{MgCl}_{2}$ and $6 \mu \mathrm{l}$ of DNA template. The amplification was performed in a thermal cycler (Carbett Research, Australia). PCR conditions used were one cycle of $95^{\circ} \mathrm{C}$ for $2 \mathrm{~min}, 30$ cycles of $94^{\circ} \mathrm{C}$ for $1 \mathrm{~min}, 58^{\circ} \mathrm{C}$ for $1 \mathrm{~min}, 72^{\circ} \mathrm{C}$ for $1 \mathrm{~min}$ and one cycle of $72^{\circ} \mathrm{C}$ for $10 \mathrm{~min}$. PCR products were analysed in $1 \%$ agarose gel electrophoresis in $1 \mathrm{X}$ TBE buffer containing ethidium bromide and the gel was observed under (UV) transilluminator and photographed.

\section{Results and Discussion}

The mixed infections of CYMV and CGB from citrus were detected simultaneously from the midrib of leaves from sweet orange trees infected by both pathogens (Fig. 1C). CYMV could be detected from midrib as well as leaf lamina, while CGB was detectable only from midrib and not from leaf lamina of citrus trees infected by both pathogens.

In the present investigation amplified product of expected sizes i.e. $726 \mathrm{bp}$ and 451 bp respectively were successfully obtained from CYMV and greening infected citrus leaf samples by duplex PCR by using two different set of primer pairs specific for ORF-III region in CYMV and $16 \mathrm{~S}$ rDNA region in $\mathrm{CGB}$, while no amplicon was obtained in healthy plant samples (Fig. 2).

Evaluation of 23 field samples from citrus orchards in Citrus Research Station, Tirupati, 10 samples showed the presence of only CGB. Of 23 samples, 10 trees showed the amplification CYMV of and CGB both, 
indicating the presence of mixed infection in the field. Amplification of no pathogens was observed in 3 samples. The detection of greening bacterium is sometimes erratic because of their uneven distribution in plants. Nevertheless, duplex PCR is a sensitive technique for detection of CYMV and CGB as both could be detected in 10 samples out of samples showing apparent symptoms of both pathogens.

Fig.1a Citrus Yellow Mosaic virus symptoms on sweet orange leaves

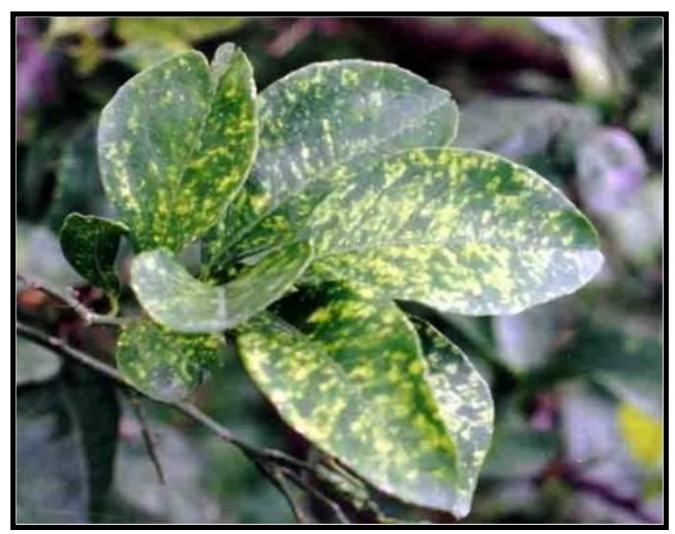

Fig.1b Citrus Greening Bacterium symptoms on sweet orange leaves

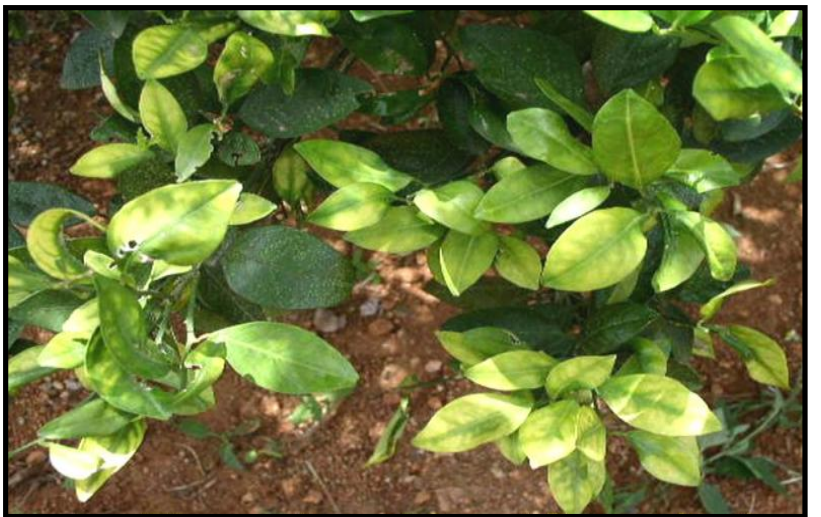

Fig.1c Mixed infections of CYMV and CGB on sweet orange tree

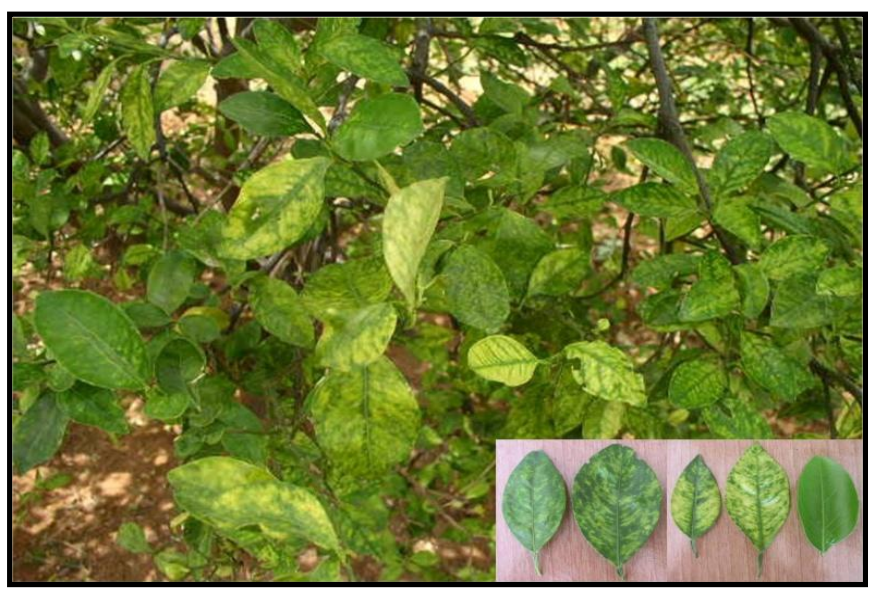


Fig.2 Simultaneous detection of CYMV and CGB from naturally infected field samples by duplex PCR

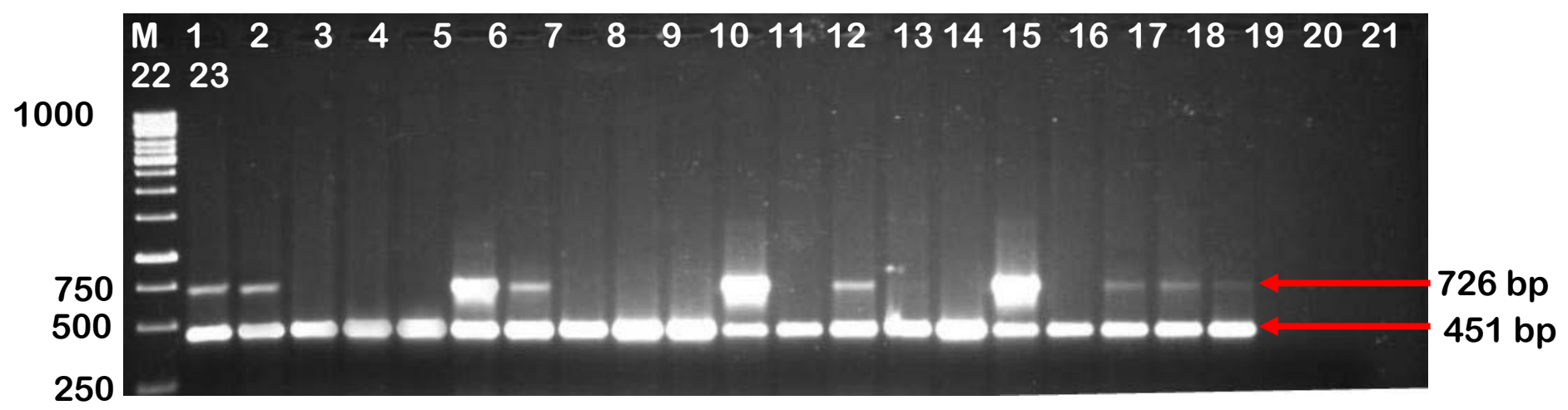

The duplex PCR can save time and energy because it can be performed in a single reaction. Although, there is no such reports for simultaneous detection of bacterial and viral pathogens from citrus leaves but a protocol has been used for the detection of a bacterium and viruses in olive tree (Bertolini et al., 2003).

In this study, detection of greening bacterium directly from infected tissues is important. The use of DNA from midrib of leaves of infected trees demonstrated that, in case of mixed infection of citrus trees, template DNA can be isolated from midrib alone for both bacterial and viral pathogens. This was confirmed in our field evaluation studies where duplex PCR could detect the infection of CGB and CYMV either singly or together if present in the tree. Performance of a duplex PCR with both pairs of primer could provide information with regards to the individual infection of each pathogen as well as the mixedinfections in sweet orange trees where both pathogens are found frequently.

Optimization of duplex PCR reaction needs adjustments in the amount of primers, dNTPs and $\mathrm{MgCl}_{2}$ concentration and other parameters used in the standard PCR
(Chamberlain and Chamberlain, 1994). In the present study, we optimised the duplex PCR conditions and amplified product of expected sizes i.e. 726 bp obtained from CYMV and 451 bp from CGB. Consequently, the duplex PCR, which can detect and identify simultaneously greening bacterium and CYMV in citru s trees, appears suitable for large-scale indexing. This study provides a convenient reproducible and rapid method for the detection of mixed infections as well as single infection of two pathogens in citrus and determines their extent of mixed infection. It can also be useful for the phytosanitary assay in plant quarantine.

\section{References}

Ahlawat, Y.S., Baranwal, K., Thinley, D.D. and Mazumder, S. 2003. First report of citrus greening disease and associated bacterium Candidatus Liberibacter asiaticus from Bhutan. Plant Dis., 87: 448.

Ahlawat, Y.S., Byadgi, A.S., Varma, A. and Chakraborty, N.K. 1995. In: Detection of Plant Pathogens and their Management (Verma P., Verma A., and Kumar D., eds.). Angkor Publishers (P) Ltd., New Delhi 
Ahlawat, Y.S., Chenulu, V.V., Vishwanath, S.M. and Pandey, P.K. 1984. Studies on a mosaic disease of citrus in India. Current Sci., 54: 873-874.

Ahlawat, Y.S., Pant, R.P., Lockhart, B.E.L., Srivastava, M., Chakraborty, N.K. and Varma, A. 1996a. Association of badnavirus with citrus mosaic disease in India. Plant Dis., 80: 590-592.

Ahlawat, Y.S., Varma, A., Pant, R.P., Shukla, A. and Lockhart, B.E.L. 1996b. Partial characterization of a Badna virus Associated with citrus yellow mosaic disease in India. p. 209217. In: Proc. 13th Conf. IOCV., IOCV, Riverside, California.

Baranwal, V.K, Mazumder, S., Ahlawat, Y.S. and Singh, R.P. 2003. Sodium sulphite yields improved DNA of higher stability for PCR detection of Citrus yellow mosaic virus from citrus leaves. J. Virol. Methods, 112:153156.

Bertolini, E., Olmos, A., Lopez, M.M. and Cambra, M. 2003. Multiplex nested reverse transcription-polymerase chain reaction in a single tube for sensitive and simultaneous detection of four RNA viruses and Pseudomonas savastanoi pv.savastanoi in Olive trees. Phytopathol., 93: 286-292.

Bove, J., Chau, N., Trung, H., Bourdeaut, J. and Garnier, M. 1996. Huanglongbing (greening) in Viet Nam: Detection of Liberibacter asiaticum by DNAhybridization with probe In 2.6 and PCR-amplification of $16 \mathrm{~S}$ ribosomal DNA. Proceedings of the 13th Conference, International Organization of Citrus Virologists. Riverside, California. 258-266.

Chamberlain, J.S. and Chamberlain, J.R. 1994. Optimization of multiplex PCRs, in The polymerase chain reaction, edited by $\mathrm{K} B$ Mullis, $\mathrm{F}$ Ferre \& R A Gibbs (Birkhauser,
Boston, MA, USA), 38-46.

Gopal, K., Reddy, G.S., Reddy, M.R.S., Reddy, B.C. and Rao, A.R.K . 1999. Citrus decline in Andhra PradeshCauses and theirmanagement, in Proc Int Symp on Citriculture (Nagpur, India): 709-718.

Hocquellet, A., Bove, J.M. and Garnier, M. 2000. Isolation of "Candidatus Liberibacter" genes by RAPD and New PCR detection technique, in Proc 14th Conf IOCV (IOCV, Riverside, California): 363-368.

Jagouiex, S., Bove, J.M., Garnier, M. 1996. PCR detection of two "Candidatus" liberobacter species associated with greening disease of citrus. Mol. Cell Probes, 10: 43-50.

Korsten, L.G., Sanders, H.J.Su., Garnier, M., Bove, J.M. and Kotze, J.M. 1993. Detection of citrus greening-Infected citrus in South Africa using a DNA probe and monoclonal antibodies, in Proc 12th Conf IOCV ( IOCV, Riverside, California): 224-234

Lockhart, B.E.L., and Olszewski, N.E. 1993. Serological and genomic heterogeneity of banana streak badnavirus: Implications for virus detection in Musa germplasm, in Breeding banana and plantain for resistance to disease and pests, edited by $\mathrm{J}$ Ganry (International Network for Improvement of Banana and Plantain, Montpellier, France): 105-113.

Murty, V.D. and Reddy, G.S. 1975. Mosaic - A transmissible disorder of sweet oranges. Indian Phytopathol., 28: 398-399.

Reddy, G.S. and Murti, V.D. 1985. Indian Council of Agricultural Research Publication, New Delhi, 590-593.

Singh, R.P. and Nie, X. 2003. Multiple virus and viroid detection and strain separation via multiplex reverse transcription polymerase chain 
reaction. Can. J. Plant Pathol., 25:127-134.

Varma, A., Ahlawat, Y.S., Chakraborty, N.K., Garnier, M. And Bove, J.M. 1993. Detection of Greening BLO by electron microscopy, DNA hybridization in citrus leaves with and without mottle from various regions in India, in Proc 12thConf. IOCV (IOCV, Riverside, California): 280-285.

\section{How to cite this article:}

Gopi, V., T. Gouri Sankar, K. Gopal and Mukunda Lakshmi, L. 2016. Molecular Detection of Citrus Yellow Mosaic Virus (CYMV) and Citrus Greening Bacterium (CGB) in Sathgudi Sweet Orange by Duplex Polymerase Chain Reaction (dPCR). Int.J.Curr.Microbiol.App.Sci. 5(12): 726-732. doi: http://dx.doi.org/10.20546/ijcmas.2016.512.083 